\title{
Proceeding
}

9th INSHS International Christmas Sport Scientific Conference, 4-6 December 2014. International Network of Sport and Health

Science. Szombathely, Hungary

\section{The social self-efficacy of students: a research school of Physical Education and sports at Anadolu University}

\author{
DILEKK YALIZ SOLMAZ \\ Anadolu University, Eskişehir, Turkey
}

\begin{abstract}
Yaliz, D. (2015). The Social Self-Efficacy of Students: A Research School of Physical Education and Sports at Anadolu University J. Hum. Sport Exerc., 9(Proc1), pp.S227-S235. The social self-efficacy of students: a research school of physical education and sports at Anadolu University. The aim of this study was to investigate social self-efficacy perception of Physical Education and Sports School students at Anadolu University in terms of gender, departments and ages. 274 Anadolu University Physical Education and Sports School students were formed the research universe. Data were collected by means of "Social Selfefficacy Scale" which was originally developed by Smith-Betz (2000) and reorganized by Palancı (2004) in Turkey. The survey consists of two parts. In the first section contains demographic factors. Second part of the questionnaire is to determine social self-efficacy perception of students in the School of Physical Education and Sports at Anadolu University and consisted of 25 items. In the data analysis, "arithmetic mean and standard deviation" for numerical comparisons were used. In order to determine the differences among attitudes, t-test was used for two-way comparisons for independent groups and ANOVA was used in order to compare variables of groups more than two. In the statistical analysis, 0.05 was accepted as the significance level. The results of the analyses indicated that the social self-efficacy perception of students use differentiated according to gender and departments, but didn't differentiate according to ages. Key words: SELF-EFFICACY, SOCIAL SELF-EFFICACY, PHYSICAL EDUCATION AND SPORTS.
\end{abstract}

Corresponding author. Faculty of Sport Sciences, Anadolu University, 26555. Eskişehir, Turkey.

E-mail: ilekyaliz@anadolu.edu.tr

9th INSHS International Christmas Sport Scientific Conference, 4-6 December 2014. International Network of Sport and

Health Science. Szombathely, Hungary.

JOURNAL OF HUMAN SPORT \& EXERCISE ISSN 1988-5202

(c) Faculty of Education. University of Alicante

doi:10.14198/jhse.2015.10.Proc1.10 


\section{INTRODUCTION}

Self-efficacy is largely concerned with their beliefs of how well people will be able to perform in given conditions (Bandura, 1986). Self-efficacy is related not to the skills one has but with beliefs of what one can do with whatever skills one possesses (Claggett \& Goodhue, 2011). It is emphasized that self-efficacy plays an important role in gaining a new skill or experiencing new learning, and then putting this new skill or learning into practice (Kotaman, 2008).

Individuals' self-efficacy beliefs also have been shown to influence certain thought patterns (e.g., worries, goal intentions, causal attributions) and emotional reactions (e.g., shame, pride, sadness, happiness) that also influence motivation (Bandura, 1997). Individuals with strong self-efficacy judgments will continue to work hard for accomplishment, even if difficult tasks become apparent. Once engaged in the task, the positive perception of self-efficacy will drive the individual to persist to completion. Upon the successful completion of tasks, positive self-efficacy of the individual will be strengthen even more (Bandura, 1997; Ritter etd., 2001; Lewandowski, 2005). Individuals with low self-efficacy beliefs will allow negative experiences to weaken their self-efficacy as they "give up" working toward the goal. In other words, those who have a low efficacy expectation will allow fear and apprehension of obstacles to turn them away. If the individual with a weak self-perception should attempt the task, this person is more likely to surrender in the presence of obstacles, ultimately resulting in a weaker self-efficacy (Bandura, 1997; Gibson \& Dembo, 1984; Smylie, 1990; Pajares, 2002).

Self-efficacy is affected whether an individual can make a behavior, how much effort will be spent to define the behavior of a successful and how much would be the face of persistent obstacles faced (Esen \& Çelikkaleli, 2008). Social self-efficacy is one of the most important areas of self-efficacy. Social self-efficacy is one of the variables that may significantly affect individuals' social behavior.

Wei, Russell \& Zakalik (2005) defined social self-efficacy as an 'individuals' belief that they are capable of initiating social contact and developing new friendships". Social self-efficacy is helping to be evaluated as successful in the social relations of the individual himself (Bandura, 1977). According to Connolly (1989), social self-efficacy includes such skills as participation in a social group or activity, social boldness, friendly behaviors, and getting and giving help. An individual with strong social self-efficacy will be likely to seek out social experiences with the expectation that those experiences will be successful. If social experiences are perceived as failures, an individual may lower their efficacy expectations and reduce the frequency of social interaction (Butler, 2012).

Because university students come from very different socio-cultural environment and are at the end of a turbulent period of development, accepted adolescence, has drawn the attention of researchers. Some of the young people, aged between 18-25, which overlaps with the university education for most, wants to be a leader, some wants a girl or boy friend and some to make a revolution inside her or his personality (KIlıçç, 1992). The individual wants to be belonging to a group in this period. This may be a sports club, a political organization or a group of friends in the neighborhood (Kulaksızoğlu, 2000).

Özgüven (1992) states that the influence of the family decreases at university level and the value system of friend circles becomes more effective with regards to guidance of behavior of the individual. The individual begins to interpret and perceive himself or herself as a self-efficacy person and this understanding leads the individual to be more consistent in his or her interactions; to have more self-reliance and to get more efficient results with the help of appropriate guidance. Additionally, when the self-efficacy expectations of 
the students are low, this has a negative impact on their success at any stage of their education and on establishing an effective communication with their environment.

The concept of self-efficacy has been a subject for many researches abroad. In Turkey, recently, there is a growing interest in studies about self-efficacy, as well. However, there are not many researches on social self-efficacy. Therefore, this study is important in fulfilling the gap in this field and in helping the university students gain the necessary features to become more qualified.

\section{MATERIAL AND METHODS}

\section{Participants}

Two hundred seventy-four students from first, second, third and fourth grades of the Physical Education and Sports Teacher Training, Recreation, Coaching and Sport Management Program within the School of Physical Education and Sports of Anadolu University, participated in this study. The data were gathered during 2012-2013 Academic Year.

\section{Data Collection Tool}

By collecting data of research, it was used "Social Self-efficacy Perception Scale" which was enhanced by Smith-Betz (2000), translated into Turkish by Palancı (2004), and studied with validity and reliability studies. This scale aims to measure perceptions of self-efficacy of college students and adolescents. The scale is a 5-point Likert-type scale and high scores receiving from the scale shows that the level of social self-efficacy beliefs are high.

Turkish adaptation of it, the Social Self-efficacy Perception Scale's Cronbach alpha reliability coefficient was .89. In this study, consequence of repeated analysis of the reliability of the scale is determined ".88", respectively. Since this value is a higher than ".70" standard which is adequate for research, it was concluded that that scale can be used in research as a whole (Kalaycl, 2008).

\section{Analysis}

After implementing as planned the data collection tool used in the study of students, responses to scale have been reviewed individually by the researcher. There were a few scales left unmarked or left blank. They were left outside the scope of the assessment. Before beginning the analysis of data related to the study of statistical methods to determine compliance with the SPSS program have analyzed the distribution of the data, the distribution of the kurtosis and skewness were studied. Even though in the literature there are no standard values certain accepted, when the normal skewness and kurtosis values are \pm 2 and \pm 7 intervals, Chou \& Bentler (1995) and Curan, West \& Finch (1996) stated they show normal distributions. A normal distribution is a cluster that each of which may be defined by a mean and standard deviation of the distribution.

When the Physical Education and Sports School students' Social Self-efficacy Perception Scale scores are analyzed in terms of kurtosis and skewness, Chou \& Bentler (1995) and Curan, West \& Finch (1996) stated that the kurtosis and skewness of the data showed a normal distribution according to the values they said. After analysis of the distribution of data, of the tests to be used in order to decide whether the examined homogeneous (Levene $>0.05$ ), it is determined that the data are homogeneous. 
This study employed statistical calculations (mean, standard deviation, T-Test, one way ANOVA) in measuring social self-efficacy perception of the participants. The T-Test is used to compare the differences between the two means, and ANOVA is used to compare three or more means. In this present study, male and female participants' use of reading strategies was compared by making use of the independent samples T-Test. As there are participants belonging to different levels, one-way ANOVA was used to determine the significant differences between the groups indicated. Statistical analysis for the realization of the significance level was adopted at .05.

\section{RESULTS}

Table which is showing about the personal characteristics of students participating on research's findings are given below.

\begin{tabular}{lcc} 
Table 1. Personal Characteristics of Students $(n=274)$ & & \\
\hline Personal Characteristics & $\mathrm{N}$ & $\%$ \\
\hline Gender & 186 & 67.9 \\
Male & 88 & 32.1 \\
$\quad$ Female & & \\
\hline Departments & 84 & 30.7 \\
Physical Education and Sports Teacher Training & 44 & 16.1 \\
Sport Management & 84 & 30.7 \\
Coach Training & 62 & 22.6 \\
Recreation & & \\
Ages & 98 & 35.8 \\
18-20 & 107 & 39.1 \\
$21-23$ & 60 & 21.9 \\
$24-26$ & 9 & 3.3 \\
$27-29$ & & \\
\hline
\end{tabular}

As seen in Table 1, 32.1\% of the students in the research of the study population were female, $67.9 \%$ are male. As regards students studying their departments, Physical Education and Sports Teacher Training and Coaching Training Department students consist of majoring 30.7\%, Recreation Department students consist of $22.6 \%$ and Department of Sport Management students consist of $16.1 \%$ of all population. According to ages, $35.8 \%$ is for $18-20$ ages, $39.1 \%$ is for $21-23$ ages, $21.9 \%$ is for $24-26$ ages and $3.3 \%$ is for 27-29 ages' students' population of rate involved in the study.

Table 2. The social self-efficacy perception according to genders of students $(n=274)$

\begin{tabular}{|c|c|c|c|c|c|c|c|}
\hline & & $N$ & $M$ & SSt & $t$ & $d f$ & $p$ \\
\hline \multirow{2}{*}{$\begin{array}{l}\text { Social } \\
\text { Self-Efficacy }\end{array}$} & Female & 88 & 86.10 & 12.55 & \multirow{2}{*}{-6.56} & \multirow{2}{*}{272} & \multirow{2}{*}{$.00(<.05)$} \\
\hline & Male & 186 & 96.02 & 11.26 & & & \\
\hline
\end{tabular}


According to table 2, there is a statistically difference between mean scores of social self-efficacy perception of female and male students. Social self-efficacy of male $(M=96.02)$ are seen to be higher than the average female $(M=86.10)$.

Table 3. Descriptive statistics table of students social self-efficacy levels according to departments $(n=$ 274)

\begin{tabular}{lllll}
\hline & & $N$ & $M$ & SS \\
\hline \multirow{4}{*}{$\begin{array}{l}\text { Social } \\
\text { Self-Efficacy }\end{array}$} & Physical Education and Sports Teaching & 84 & 90.21 & 12.31 \\
\cline { 2 - 5 } & Sports Management & 44 & 91.84 & 12.59 \\
\cline { 2 - 5 } & Coach Training & 84 & 97.18 & 11.49 \\
\cline { 2 - 5 } & Recreation & 62 & 91.21 & 11.57 \\
\hline
\end{tabular}

According to table 3, students' social self-efficacy compared according to the departments it is seen that the differences between the averages. In order to examine these differences, the results of the one-way analysis of variance are presented below.

Table 4. The social self-efficacy perception according to departments of students $(n=$ 274)

\begin{tabular}{llccccc}
\hline \multirow{2}{*}{ Source of Variation } & $d f$ & $\begin{array}{c}\text { Sum of } \\
\text { Squares }\end{array}$ & $\begin{array}{c}\text { Mean } \\
\text { Squ. }\end{array}$ & $F$ & $p$ \\
\hline \multirow{3}{*}{$\begin{array}{l}\text { Social } \\
\text { Self-Efficacy }\end{array}$} & Between Gr. & 3 & 2369.0 & 789.7 & & \\
\cline { 2 - 5 } & Within Gr. & 270 & 40652.6 & 150.6 & & \\
\cline { 2 - 5 } & Total & 273 & 43021.6 & & & \\
\hline
\end{tabular}

According to table 4, there is a statistically difference according to departments of students between mean scores of social self-efficacy perception.

Table 5. Descriptive statistics table of students social self-efficacy levels according to ages $(n=274)$

\begin{tabular}{lcccc}
\hline & & $N$ & $M$ & $S S$ \\
\hline \multirow{3}{*}{$\begin{array}{l}\text { Social } \\
\text { Self-Efficacy }\end{array}$} & $18-20$ & 98 & 91.65 & 12.16 \\
\cline { 2 - 5 } & $21-23$ & 107 & 94.22 & 12.91 \\
\cline { 2 - 5 } & $24-46$ & 60 & 91.97 & 12.71 \\
\cline { 2 - 5 } & $27-29$ & 9 & 95.00 & 11.38 \\
\hline
\end{tabular}


According to table 5, students' social self-efficacy is analyzed according to age shows that there are differences between the averages. In order to examine these differences, the results of the one-way analysis of variance are presented below.

Table 6. The social self-efficacy perception according to ages of students $(n=274)$

\begin{tabular}{llccccc}
\hline \multirow{2}{*}{ Source of Variation } & $d f$ & Sum of Squares & Mean Squ. & $F$ & $p$ \\
\hline \multirow{2}{*}{$\begin{array}{l}\text { Social } \\
\text { Self-Efficacy }\end{array}$} & Between Gr. & 3 & 430.9 & 143.6 & & \\
\cline { 2 - 5 } & Within Gr. & 270 & 42590.8 & 157.7 & $.91(<1)$ & $.44(>.05)$ \\
\cline { 2 - 5 } & Total & 273 & 43021.6 & & \\
\hline
\end{tabular}

According to table 6 , there is no statistically difference according to departments of students between mean scores of social self-efficacy perception.

\section{DISCUSSION}

In research which is studied is to examine if Anadolu University Physical Education and Sports School students' social self-efficacy perception differs according to their level of gender, departments and ages or not we reached some results:

When it is examined the Physical Education and Sports School students' social self-efficacy perceptions according to their gender, it is observed a significant difference. Accordingly, social self-efficacy of men is higher than girls. The difference is a result of different attitudes towards boys and girls in our society; while boys are given more responsibility and work, thus enhancing their self-reliance, the girls are given less responsibilities, negatively affecting their social self-sufficiency and self-confidence. In other words, boys are more sociable than girls and can get related to social environments more freely without the fear of being misunderstood.

These results obtained from this study are similar to the results of various studies. One of these studies was conducted in 2009 by Türk. In Türk's study, researcher examined the physical education and sports teacher's self-efficacy expectation level through different variances, who teach in Nevşehir. In conclusion, it is showed that the between gender and self-efficiency levels showed meaningful differences. According to the results, the female teachers were found to have high self-efficacy than male teachers. Similarly, in research of Aydıner (2011) with high school students, it was concluded that students' general self-efficacy levels are different according to gender. Accordingly, participants' gender characteristics affected the level of general self-efficacy. Another study was carried out in 2010 by the Dönmez. In Dönmez's study, he carried out to determine if there is a relationship between social efficacy and problem solving abilities of students in Department of Physical Education and Sports Teaching (1 ${ }^{\text {st }}, 2^{\text {nd }}, 3^{\text {rd }}$ and $4^{\text {th }}$ grades). In conclusion, there is a significant difference between the points of girls and boys. This difference is towards boys. In the research to determine the situation which was studied by Alemdağ (2013), researcher showed that there is a statistically difference between scores of social self-efficacy perception and genders. For all that, these results obtained from this study are contrast to the results of various studies. One of these studies was conducted in 2007 by Çubukçu \& Girmen. In Çubukçu \& Girmen's studies, they examined the social self-efficiency perception of candidate teacher. In conclusion, it is showed that there is no statistically 
difference according to genders of students between mean scores of social self-efficacy perception. Similarly, in research of İkiz \& Yörük (2013) with teacher candidate, it is observed that there was a statistically significant difference between male and female teachers of general self-efficacy. As a result, it supports the findings of emerging between social self-efficiency perception of male and female students obtained by Aydıner (2011), Türk (2009), Dönmez (2010) and Alemdağ (2013).

When evaluated in terms of departments of Physical Education and Sports School students, it is seen that the difference between levels of social self-efficacy perceptions are significant. The reason for this result is different from each other in areas of course content. Additionally, the perception of self-efficacy is generally higher for students getting training in becoming a trainer (coach) because they are elected through a special talent exam different from the departments of sports administration and recreation, because they have a history in sportsmanship parallel to the profession of training; because they take part in different social environments at different times thanks to various competitions an activities they attend, and being in relation with sportspersons, trainers and administrators from different cultures; and also because that they feel in their daily lives the self confidence that sports brings to an individual. These findings obtained from this study are consistent with the result of obtained to significant relation between social self-efficiency perception and programs of teacher candidate by Çubukçu \& Girmen (2007).

According to ages of students of Physical Education and Sports School, there wasn't any significant difference between social self-efficacy perceptions. Accordingly, it can be said that students' social selfefficiency perception levels is independent from their age levels and social self-efficiency perception is a similar degree of frequency. In other words, the reason of the absence of significant differences can be considered to be close of the age range.

These results obtained from this study are similar to the results of various studies. The research conducted by Alabay (2006) shows that the comparison of self-sufficiency points taken by pre-school teacher candidates to their ages does not lead to a meaningful differentiation according to age. The research by Zencirci (2008) tried to find out whether the self-sufficiency points showed any difference with regards to the age of the teacher, by making use of the Kruskal Wallis-H Test; but the results were not interpreted to be meaningful statistically. At Türk (2009)'s study, although there is a positive relationship between the teacher's age and levels of self-efficacy, there is no correlation significant at 0.05 level. However, these findings obtained from research, Alemdağ (2013) and Dönmez (2010)'s research results are contradictory.

\section{CONCLUSIONS}

As a result, this study has been conducted with students studying in departments of a college of Physical Education and Sports College of Physical Education and Sports Teacher Coaching, Recreation and Sport Management. It is thought that this study will provide significant contributions to literature by comparing with students of other universities departments of Physical Education and Sports of Turkey and including in other faculty and departments' students. For branches related to self-efficacy seems to be quite a lot of work. However, the number of researches about social self-efficiency scale developed for determined the qualification status of the individual's social environment are quite limited. Therefore, it is proposed researches of this area for contribute to the literature related to social self-efficacy. Designed quantitative and qualitative researches will improve on the scope of work. In addition, necessary studies in order to increase students' level of social self-efficacy can be made (seminars, projects, etc). 


\section{REFERENCES}

1. Alabay, E. (2006). İlköğretim okul öncesi öğretmen adaylarının fene karşı oz yeterlilik inanç düzeylerinin incelenmesi. Yeditepe Universitesi Eğitim Fakültesi Dergisi 2(1), pp.1-10.

2. Alemdağ, S. (2013). Öğretmen adaylarında fiziksel aktiviteye katılım, sosyal görünüş kaygısı ve sosyal öz-yeterlik ilişkisinin incelenmesi. PhD Thesis. Karadeniz Teknik Üniversitesi Eğitim Bilimleri Enstitüsü Beden Eğitimi ve Spor Anabilim Dalı, Trabzon.

3. Aydıner, B.B. (2011). Üniversite öğrencilerinin yaşam amaçlarının alt boyutlarının genel öz-yeterlik yaşam doyumu ve çeşitli değişkenlere göre incelenmesi. Master's Thesis. Sakarya Üniversitesi Eğitim Bilimleri Enstitüsü, Sakarya.

4. Bandura, A. (1977). Social Learning Theory. Englewood Cliffs, N. J. Prentice Hall.

5. Bandura, A. (1986). Social Foundation of Thought and Action: A Social Theory. Englewood Cliffs, Nj: Prentice Hall.

6. Bandura, A. (1997). Self-Efficacy: The Exercise of Control. New York: Freeman.

7. Butler, B.M. (2012). An investigation of social self-efficacy and depressed mood in adults with autism spectrum disorders. Master Thesis. The Ohio State University, Graduate Program in Psychology.

8. Chou, C., \& Bentler, P.M. (1995). "Estimates and Tests in Structural Equation Modelling." Rick H. Hoyle (Eds.), Structural Equation Modelling: Concepts, Issues and Applications, Thousand Oaks, CA: Sage.

9. Claggett, J.L., \& Goodhue, D.L. (2011). Have is researchers lost Bandura's self-efficacy concept? A discussion of the definition and measurement of computer self-efficacy. The 44th Hawaii International Conference on System Sciences

10. Connolly, J. (1989). Social self-efficacy in adolescence: relations with self-concept, social adjustment and mental health. Canadian Journal of Behavior Science Review, 21 (3), pp. 258-269.

11. Çubukçu, Z., \& Girmen, P. (2007). Öğretmen adaylarııın sosyal öz-yeterlik algılarının belirlenmesi. Eskişehir Osmangazi Üniversitesi, Sosyal Bilimler Dergisi, 8(1), pp.57-74.

12. Curan, P.J., West, S.G., \& Finch, J.F. (1996). The robustness of test statistics to non-normality and specification error in confirmatory factor analysis. Pyschological Methods, 1(1), pp.16-29.

13. Dönmez, K.H. (2010). Beden eğitimi ve spor öğretmenliği bölümü öğrencilerinin (1., 2., 3., ve 4. sınıf) sosyal öz-yeterlikleri ile problem çözme becerileri arasındaki ilişkinin incelenmesi. PhD Thesis. Gazi Üniversitesi Eğitim Bilimleri Enstitüsü Beden Eğitimi ve Spor Öğretmenliği Ana Bilim Dalı, Ankara.

14. Esen, B.K., \& Çelikkaleli, Ö. (2008). Universite öğrencilerinin sosyal yetkinlik düzeyleriyle sürekli öfke ve öfke ifade biçimlerinin incelenmesi. Türk Psikolojik Danışma ve Rehberlik Dergisi, 29(3), pp. 37-49.

15. Gibson, S., \& Dembo, M. (1984). Teacher efficacy: a consruct validation. Journal of Educational Psychology, 76 (4), pp.569-582.

16. İkiz, F.E., \& Yörük, C. (2013). Öğretmen adaylarının öz-yeterlik düzeyleri ile aile işlevlerinin incelenmesi. Uşak Üniversitesi Sosyal Bilimler Dergisi, 6(1), pp.228-248.

17. Kalaycı, Ş. (2008). SPSS Uygulamalı Çok Değişkenli Istatistik Teknikleri. Ankara: Asil Yayın Dağıtım Ltd. Şti.

18. Kılıççı, Y. (1992). Okulda Ruh Sağlığı. Ankara: Şafak Matbaacılık.

19. Kotaman, H. (2008). Öz-yeterlik inancı ve öğrenme performansının geliştirilmesine ilişkin yazın taraması. Eğitim Fakültesi Dergisi, 21(1), pp.111-133. http://kutuphane. Uludağ. edu. tr/Univder/uufader. Htm.

20. Kulaksızoğlu, A. (2000). Ergenlik Psikolojisi. İstanbul: Remzi Kitabevi. 
21. Lewandowski, K.H.L. (2005). A study of the relationship of teachers' self-efficacy and the impact of leadership and professional development. PhD Thesis. Indiana University of Pennsylvania.

22. Özgüven, E.I. (1992). Üniversite öğrencilerinin sorunları ve baş etme yolları. Hacettepe Üniversitesi Eğitim Fakültesi Dergisi, 7, pp.5-13.

23. Pajares, F. (2002). Overview of social cognitive theory and self-efficacy. http://www.emory.edu/EDUCATION/mfp/eff.html.

24. Palancı, M. (2004). Universite öğrencilerinin sosyal kaygı problemlerini açıklama ve gidermeye yönelik oryantasyonlu bir yardım modelinin geliştirilmesi. PhD Thesis. KTÜ Sosyal Bilimle Enstitüsü, Trabzon.

25. Ritter, J.M., Boone, W.J., \& Rubba, P.A. (2001). Development of an instrument to assess prospective elementary teacher self- efficacy beliefs about equitable science teaching and learning (SEBEST). Journal of Science Teacher Education, 12(3), pp.175-198.

26. Smylie, M.A. (1990). "Teacher Efficacy at Work". In P. Reyes (Ed.), Teachers and Their Workplace. (pp. 48-66). Newbury Park: Sage.

27. Türk, N. (2009). Beden eğitimi ve spor öğretmenlerinin mesleklerine ilişkin öz yeterlik düzeylerinin incelenmesi (Nevşehir ili örneği). Master Thesis. Niğde Üniversitesi Sosyal Bilimler Enstitüsü Beden Eğitimi ve Spor Anabilim Dalı, Niğde.

28. Wei, M., Russell, D.W., \& Zakalik, R.A. (2005). Adult attachment, social self-efficacy, selfdisclosure, loneliness and subsequent depression for freshman college students: a longitudinal study. Journal of Counseling Psychology, 52(4), pp.602-614.

29. Zencirci, D.E. (2008). Görsel sanatlar öğretmeni adaylarında özgün baskının yaratıcı düşünme becerileri ve öz-yeterlik algısı üzerindeki yansıması. PhD Thesis. Dokuz Eylül Üniversitesi Eğitim Bilimleri Enstitüsü, İzmir. 